\title{
Just a closer walk with thee: New Orleans-style jazz and the Campaign for Nuclear Disarmament in 1950s Britain
}

\author{
GEORGE McKAY
}

\begin{abstract}
This article looks at a particular moment in the relation between popular music and social protest, focusing on the traditional (trad) jazz scene of the 1950s in Britain. The research has a number of aims. One is to reconsider a cultural form dismissed, even despised by critics. Another is to contribute to the political project of cultural studies, via the uncomplicated strategy of focusing on music that accompanies political activism. Here the article employs material from a number of personal interviews with activists, musicians, fans from the time, focusing on the political development of the New Orleans-style parade band in Britain, which is presented as a leftist marching music of the streets. The article also seeks to shift the balance slightly in the study of a social movement organisation (the Campaign for Nuclear Disarmament, CND), from considering it in terms of its 'official' history towards its cultural contribution, even innovation. Finally, the article looks at neglected questions around Americanisation and jazz music, with particular reference to power and the past.
\end{abstract}

[A] sociology of jazz would be an absurd conception, and yet ... [w] hy should the Aldermaston marchers have followed a jazz band? (Philip Larkin, reviewing Francis Newton's [pseud. Eric Hobsbawm] The Jazz Scene, 1959 [in Palmer and White 1999, p. 41; emphasis original])

\section{Trad jazz, cultural studies and cultural politics}

On the few occasions when British trad jazz has been discussed by academics, the orthodoxy has constructed the music and the movement as conservative, retrospective, unimaginative, and worse. Iain Chambers (1986, p. 148) foregrounds 'the hermetic conservatism of revivalism', the 'homely' nature of British trad and CND beatnik style, which for him is neither as 'finger-snapping' as Kerouac's Beats nor as 'sharp' as the mods will be in a few years time. He continues:

The domestic mixture of New Orleans jazz with cups of tea, warm beer and lawn-mowed suburbia rarely pushed British bohemia towards the spirituality of modernism and movement. (Chambers 1986, p. 148)

Rather too easily positioning the politics of trad jazz within the space of English counter-modernisms of the kind expressed by George Orwell or, later, John Major here, Chambers offers a dismissive gloss which, among other effects, serves to obscure the music's political moments. Neil Nehring zones keenly in on the innate conservatism of trad jazz during what he calls 'the puerile fifties' (Nehring 1993, p. 


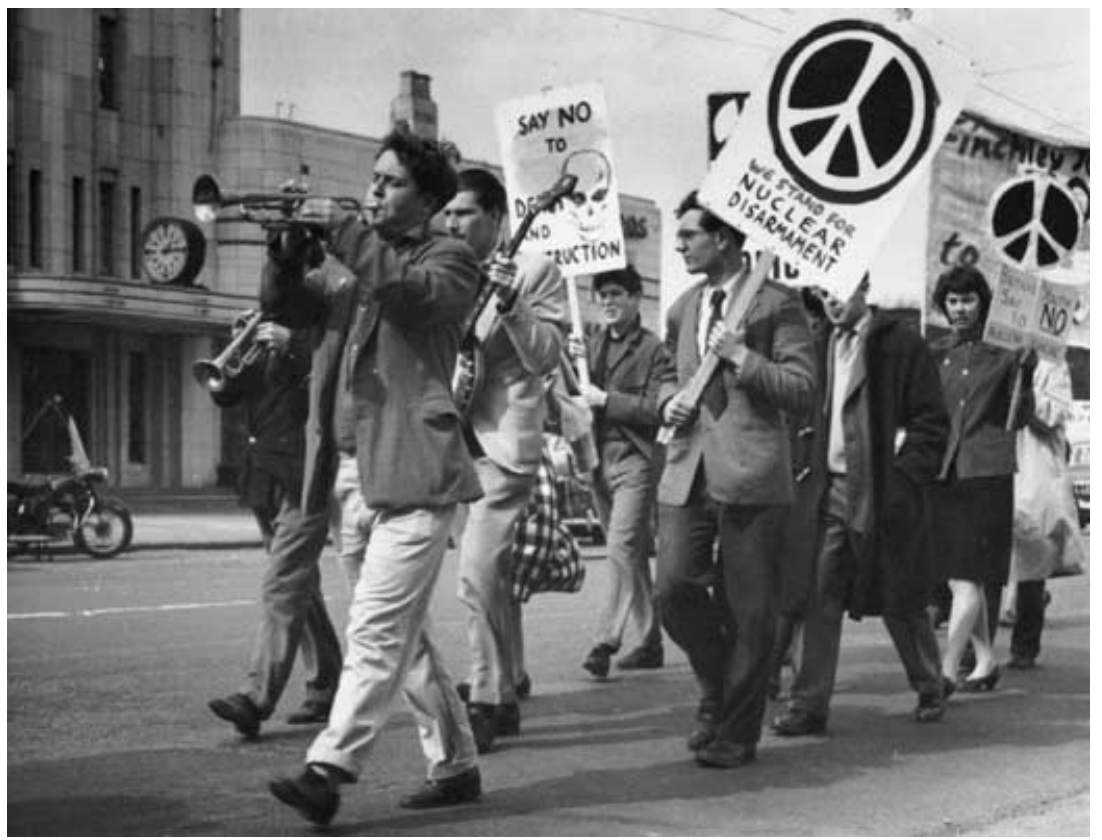

Figure 1. 'British youth say NO to nuclear suicide': Jeff Nuttall (trumpet) leads an ad hoc trad jazz ensemble on a CND march, late 1950s or early 1960 s.

210), his suspicions retrospectively confirmed by some musicians' actions twenty years on (though I am not sure trad jazz is unique in pop music in featuring musicians who politically disappoint with age, with waning popularity). The fact that Nehring dislikes the music so intensely seems only to confirm (his pleasure in making) his political judgement:

... hideous trad New Orleans jazz by the likes of Acker Bilk... It seems fitting that trad jazz, the favourite music of [Philip Larkin and] the Movement, would in its death throes invoke the Edwardian period, seemingly confirming how wrong the literary were about both popular music and English society. (By the late seventies [sic: 1976], former trad jazz stars Kenny Ball and Chris Barber played benefits for Margaret Thatcher, their politics consistent with the conservatism of that music's proponents, literary and otherwise, in the fifties.) (Nehring 1993, p. 208)

The critical problem here is that Nehring wants to read the trad movement with later eyes - as a residual culture rather than one in its emergent, even oppositional phase. Helen Taylor employs a similar problematic framework in Circling Dixie: Contemporary Southern Culture through a Transatlantic Lens, one of the very few academic books to include any detail about the extraordinary contribution of Ken Colyer to British jazz. ${ }^{1}$ In a short section on the export culture of New Orleans music, Taylor looks at trad jazz - but Colyer is presented through the prism of the Ken Colyer Trust, set up by ageing fans in the year he died, 1988. Taylor's version of trad is represented by 'a particular group of white Englishmen: middle class, financially comfortable, having repaid their mortgages and now with time on their hands' (Taylor 2001, p. 113). The 'sweet sadness' of 'nostalgic emotional appeal' is the defining feature for Taylor (2001, pp. 115, 113), and she draws attention to the fact that 
The Colyer Trust musicians and members are not very interested in the racial and social history of this music or its evolution into other forms; their concern is with saving it as a pure music, undiluted and unhybridized. (Taylor 2001, p. 115)

The significance of this critique is that Taylor herself presents a depoliticised sweet sadness: by looking only at the Trust in the 1990s rather than, say, also the musician's projects of the 1950s and 1960s, Taylor misses the more complex situation, in which Colyer's own Omega Brass Band, for example, frequently appeared at left-wing demonstrations.

Cultural critics of the left have expressed surprise at the links between jazz and the left during what became the Cold War. In The Land Without Music, Andrew Blake identifies but does little to interrogate the 'odd conjunction [of trad jazz, CND, trades union marches], given the importance of the Communist Party to union militancy, and the Soviet hatred of jazz' (Blake 1997, p. 114). Writing of the slightly earlier relation between the Communist Party and the Musicians' Union in Britain, Kevin Morgan notes 'the contingencies of communist politics in a period swinging, if one can so put it, from a broad-minded progressivism to the bigotries of Zhdanovism' (Morgan 1998, p. 124). It may be here that both Blake and Morgan overlook the contribution of the non-State left, the anarchists rather than communists, for instance, to radical activism and alternative cultures. Overall, though, what is striking about the effort of cultural studies to read trad jazz is its limited nature, and its lack of interest in the music's political role.

My project for the remainder of the article is precisely to interrogate and chart this, to use Blake's term, 'odd conjunction', to explore what may well be, after all, a leftist marching music of the streets. In doing so I acknowledge the lengthy tradition of music and mobilisation in Britain - Stephen Yeo has argued that the 'main cultural thrust of the early socialist movement was in music', for example (quoted in Waters 1990, p. 97). Early British activists aimed to create 'a socialist musical struc-

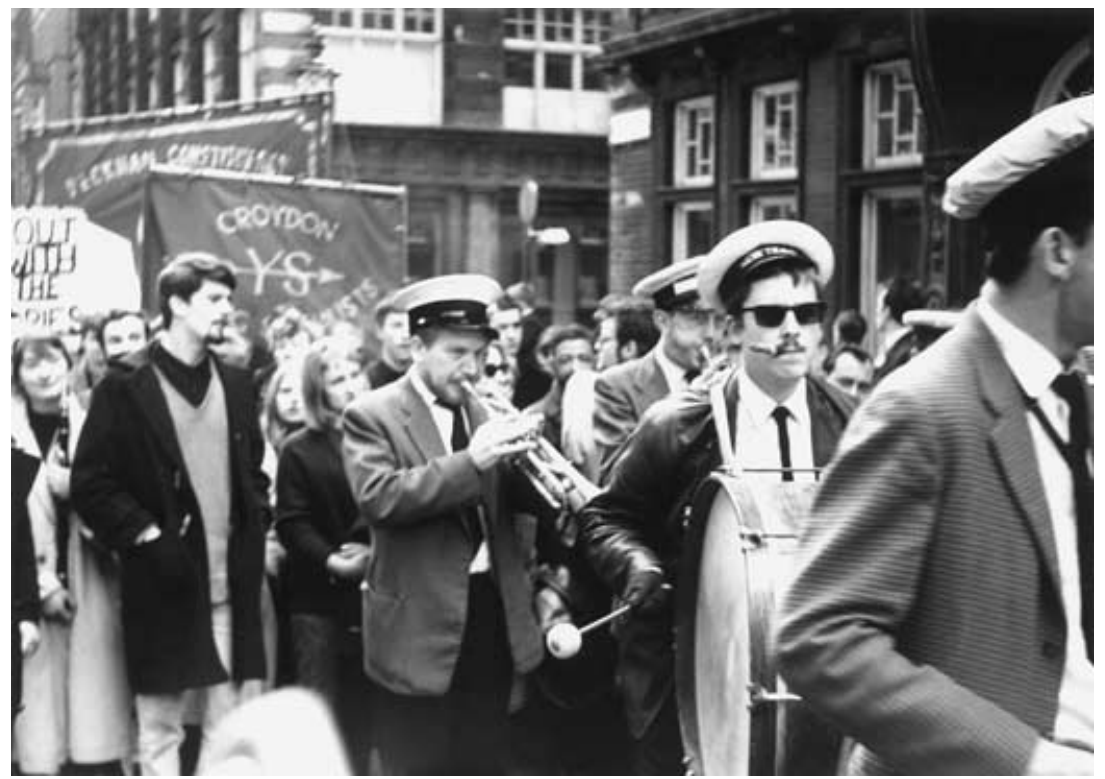

Figure 2. 'A leftist marching music of the street': Ken Colyer (trumpet) plays with the New Taeo Brass Band, May Day rally, London 1962. 
ture that stressed the importance of communal participation and offered a unique blend of songs written for the movement and works appropriated from other cultural and political traditions' (Waters 1990, p. 189). This is evident in the presence at socialist gatherings like May Day festivals of organisations such as the Clarion Vocal Union (founded 1894) of radical choirs (Waters 1990, p. 121). More pertinent for this discussion is the British brass band tradition of street music, as exemplified from Victorian times by both the Salvation Army and local mainly northern industrial bands. Trevor Herbert notes that the latter, a strong working-class music movement, 'became aligned with events such as May Day, trade-union demonstrations, and miners' galas, which epitomised working-class identity and behaviour' (Herbert 2000, p. 67).

Clearly there are ambivalent political positions within both critical readings and the pleasures of trad jazz, which may have contributed to its suspicion by cultural studies. This ambivalence is delineated by Robert Hewison, who identifies 1950s trad jazz as conservative and anti-elitist. On the one hand, the writers 'John Wain, Kingsley Amis and Philip Larkin developed a side-line as jazz critics. The critical conservatism of their poetry coloured their preference for traditional jazz', a preference also displayed in John Osborne's work. On the other hand, trad musicians produced 'an earthiness, a rawness, that was definitely, to use Nancy Mitford's phrase, non-U, and it had a proletarian, non-Mandarin vigour' (Hewison 1981, pp. 114-15). This ambivalence requires further elaboration.

The best-known jazz trumpeter of the mid-1950s in Britain was not Miles Davis, then rejecting bop for the cool linearity of modal improvisation, nor Louis Armstrong, becoming a frequent visitor now that the ludicrous and damaging twenty-year Musicians' Union ban on transatlantic music exchange was lifted (see Godbolt 1984). It was not even Ken Colyer. Jimmy Porter, angry young man of John Osborne's 1956 instant classic of a changing world, Look Back in Anger, would blow solo jazz trumpet off-stage while railing on-stage against the fact that 'it's pretty dreary living in the American Age'. The radio music Jimmy listens to is Vaughan Williams - 'Something strong, something simple, something English' (Osborne 1957A, p. 17) - so it is surprising that he does not recognise the American-ness of his great enthusiasm, jazz. Jimmy's loud, masculine, trad trumpet complicates his relation with America, even if his appreciation of the music is conventionally absolutist: 'Anyone who doesn't like real jazz, hasn't any feeling either for music or people' (Osborne 1957A, p. 48). Osborne himself wrote elsewhere of the impossibility of refusing American cultural export: 'we can't expect to put [up] some kind of tariff barrier when they start sending over their own particular anxieties and neuroses' (Osborne 1957B, p. 270), and of course one of the key cultural forms associated with the export of American neurosis has been jazz - from free jazz back to bebop back to the febrile energy of trad. But, as Nehring acutely observes, '[j]azz had long received an exemption from the Americanization thesis by English intellectuals, including members of the Movement' (Nehring 1993, p. 203).

The most interesting and productive British jazz critic from the largely conservative Movement group was Philip Larkin. Throughout the 1960s, Larkin wrote a monthly record review column for the right-wing Daily Telegraph. These writings appear to be consistently anti-modernist, and there are regular appeals to the school of what he terms the 'Old Nostalgians'. ${ }^{2}$ His fundamental uncertainty about the development of jazz is identified most powerfully by himself. In the 'footnote' prefacing the second edition he wonders whether his own writings 'type me as a dis- 
liker rather than a liker' (Larkin 1985, p. 31) of jazz, and it is the case that the (in)famous curmudgeonly introduction, written in 1968, does the collected reviews a disservice by overstating Larkin's own distaste of bop and post-bop jazzes. For each swipe at Parker or Davis or especially Coltrane (the Daily Telegraph refused to publish Larkin's untimely rant following Coltrane's death: see Larkin 1985, pp. 1868) there are many knowledgeable and enthusiastic praises - from the poet who had, after all, declared in 1965 that 'I can live a week without poetry but not a day without jazz' (quoted in Palmer and White 1999, p. 4). There are some succinct observations on the development of British jazz, too. In one 1961 review (later) entitled 'Cool, Britannia', he writes:

Not so long ago, the unlikelihood of the Briton as jazzman would have been perfectly expressed by thinking of him in a bowler hat. .. Y Yet today the bowler is worn with jolly unselfconsciousness by some of the country's most popular groups as part of their stand uniform. . . . British jazz has arrived, in Britain at any rate. (Larkin 1985, p. 42)

And on the Aldermaston marches of course, the bowler hat, newly minted crown of English jazz, would be emblazoned with a CND symbol.

The cultural politics of trad for the British left in the 1940s and particularly the 1950s were influenced by the Revivalist movement in the United States a decade or two earlier. Projects collecting and recording traditional and folk music were organised by the Library of Congress, and in 1938 Jelly Roll Morton recorded his New Orleans classics from twenty years before for Alan Lomax. In the same year, other New Orleans veterans such as Sidney Bechet and Mezz Mezzrow were also recorded. In 1945, the first recordings of New Orleans parade brass bands were made by William Russell. Recently researched recordings and publications contributed as well, and inspired groups of young white musicians to revive the early music, most notably perhaps Lu Watters' Yerba Buena Band in California. Bernard Gendron writes that the anticommercial stance of many of the revivalists played into, and reinforced, their promotion of authenticity, folklorism, tradition and affect, set against a vaguely left-wing, antifascist background' (Gendron 1995, p. 50).

The mass as well as specialist media were swiftly successful in the spread of this new-old music, nationally and internationally. In England in 1943, George Webb's Dixielanders surprised everyone with their authentic-sounding music played on Monday evenings at the Red Barn public house in Barneshurst, Kent. According to Jim Godbolt, most of the band

had worked in the local Vickers-Armstrong factory. Sociologically minded critics with various left-wing and anarchist associations saw this as an expression of working class culture and likened the band's endeavours to those of the early US black jazzmen, whose art flourished despite their subservience, socially and economically, to the white boss. The Young Communist League promoted the Dixielanders in a series of concerts at the Memorial Hall, Farringdon Street under the banner of the Challenge Jazz Club. In their paper, Challenge, they heavily emphasized the socio-political overtones of this phenomenon. (Godbolt 1984, pp. 202-3)

Trad had practical attractions, too, for the young in Britain: it was relatively easy to play passably, to listen to - and to dance/march to, it was an accessible form of music expression in keeping with the democratic sympathies of many activists and cultural workers of the time. (With its use of homemade instruments from domestic materials, the do-it-yourself form of skiffle would open wider still access to pop music performance in Britain.) Its partial origins as a marching music helped as 
well, not least for brass bands on demonstrations and other gatherings. Writing at the time, Eric Hobsbawm outlined trad's left connections:

It was a self-made music, or at least music made in the image of the amateur. Its bands - in Britain at least - resisted professionalization for the best part of ten years. Moreover, in Britain and Australia, to a very marked extent, they had and maintained links with the political left. World youth festivals, anti-nuclear marches, May Day demonstrations, or other expressions of hostility to the social status quo have rarely lacked their quota of imitation New Orleans jazz players. ... (Newton 1959, p. 76)

In summary, Paul Oliver (1990, p. 81) is perhaps most accurate about the cultural politics of trad, in his observation that it 'symbolized what its proponents chose to find in it that supported their own aims and ideologies'. He elaborates on the music's ideological multivalence:

To the communists the ensemble improvisation of the traditional band symbolized the sharing of responsibility and skills of collective creativity without individualism; to the anarchists the traditional line-up meant freedom of expression and the loose, unshackled federalism of 'head' arrangements; to liberals the music spoke of responsibility and selflessness; to conservatives, the strength and continuity of traditions ensured the basis for the individual enterprise of front-line soloists. (Oliver 1990, p. 81)

This is neat, but lacks the essential tension of such factionalising discourses as the left and jazz alike. In the United States, for instance, vehement arguments took place between modernists and revivalists, the modernists going so far as 'to accuse the "moldy figs" of "musical fascism". They variously vilified them as the "rightwingers of jazz", "the voice of reaction in music", a "lunatic fringe" (Gendron 1995, p. 46). In Britain, Kevin Morgan suggests, 'despite its rhetoric of the people, early British jazz appreciation shared with so many forms of left-wing culture an eschewal of the popular, a comradeship of the elect, which was the secret at once of its richness and its marginality' (Morgan 1998, p. 139). By the 1950s, British jazz was torn not only between revivalists and traditionalist purists, but between both these and the relatively new modernists, so much so that trouble among fans at the 1959 Beaulieu Jazz Festival merely presaged the 1960 festival's Saturday night riot between fans of tradder Acker Bilk and modernist Johnny Dankworth. ${ }^{3}$

There is one other significant aspect of cultural politics I want to look at: race. In origins, the New Orleans marching brass band was a highly significant feature of black and Creole culture in the city, not least because, as William Schafer notes, 'the brass band emerges as a major source, a gene pool, for jazz' in the late nineteenth century (Schafer 1977, p. 8). He continues: 'this band music was born of an intense, emotionally charged desire for freedom and recognition. Its militancy is not of the battlefield or the church, but of the political arena' (Schafer 1977, p. 13). ${ }^{4}$ But it is worth restating the fact that it was not until 1945 that New Orleans brass bands were actually recorded, and those recordings distributed to jazz and folk audiences (Schafer 1977, p. 60); this extraordinary time gap of perhaps half a century between the music's local formation and its recording and swift national and international recognition gave the old music a novelty, an attraction, an instant history of its own. ${ }^{5}$

And, of course, most of the new, young enthusiasts in the revivalist jazz movement, whether in California, Australia or Britain, were white. The whiteness of the trad boom in Britain is one topic that has been touched on by cultural critics. For instance, Iain Chambers writes that - at the time of bebop and the beginnings of free jazz, after all - white trad could 'conveniently overlook' the 'new, black militant 
musical consciousness' of the times by 'nostalgically evoking a mythical New Orleans of around 1900' (Chambers 1985, p. 48). Simon Frith explores the processes by which African-American music - minstrelsy, trad - was 'made safe' for suburban consumption in Britain. The only way British jazzers up to the 1950s could attempt or claim to play authentic music was, according to Frith, by making 'the music a matter of feeling, expressive of personal not social identity, of sensual not cultural need' (Frith 1988, p. 58; emphasis added). I hope to show that readings like these do not fully map on to the popular appearance of trad jazz in the 1950s at social and political demonstrations, at events in the beginnings of alternative culture, the New Left, and the white understanding of colonialism and racism - that the British, very largely white practice of trad figured in fact as a significant accompaniment to shifting social identity and political praxis at the time. This is not to suggest that what Les Back calls the 'normative whiteness' in European perspectives on jazz is absent, or that there is never correspondence between Jim Crow and John Bull, in Back's phrase (Back 2001, p. 170). For example, it is the case that the (almost entirely) white performance of trad itself could exclude a black audience in Britain. Jazz singer, anarchist, critic, CND and Anti-Apartheid Movement member George Melly, renowned for his larger-than-life renditions of blues and trad songs, now admits:

The modern jazz scene attracted lots of black people. We thought that it was because modern jazz was more contemporary, more cool and cutting edge, and that's what London's blacks wanted, whereas ours was too old music. I think as well now that black audiences may have perceived some element of Uncle Tomming in our performances. Yes, that's possible, yes. (Melly, personal interview, 25 February 2002)

I hope to show though that the argument that white British musicians and audiences (worked to) avoid the militant or cutting edge of current black American music, and by implication politics - the taming of jazz, the masking of whiteness through blackface - offers an incomplete conclusion to the complex past and politicised pleasures of the trad movement. That there was an extraordinary enthusiasm in Britain for a black music of the American South at the very time when the Civil Rights movement was progressing its struggle there provides another arena for at least sympathetic interest in that political struggle. Colin Barker was a suburban trad fan, whose experience of what he understood as the implicit politics of the music is illuminating and, I suggest, not unrepresentative.

When I went to university in 1959, I just gravitated towards CND. It kind of went with what I wanted to be, and though there had never been any formal 'politics' in the jazz scene in [my home town of] Ilford, and there were no black people around our area in that period, it was taken for granted that we all wished we could hear black American jazz musicians. I read in the newspaper about the early civil rights movement in the States, and automatically identified with it without ever thinking why. So jazz did imply a kind of connection with anti-racism, even though the term was unknown then. (Personal correspondence, 23 April 2002)

\section{Jazz in the streets: New Orleans-style brass bands on the Aldermaston marches}

You want to know why we came here? Well, the simple reason is we are lovers of good music for one thing, and if this hell of a lot goes up, we're not likely to hear good music any more! (CND marching musician, March to Aldermaston, 1958) 
In Lindsay Anderson et al.'s short documentary film of the first Aldermaston march of Easter 1958, March to Aldermaston, I counted eighteen shots of jazz bands playing (the first three are of the uniformed Omega Brass Band), and ten times trad music forms the soundtrack. The production team evidently thought trad the key musical accompaniment to the event, though it is the folk scene which has more commonly been recognised as providing the soundtrack for the campaign generally (Brunner 1983; Boyes 1993). Georgina Boyes traces distinctions as well as connections between the two musical forms:

although jazz bands provided much of the music for the marches organised by the Campaign for Nuclear Disarmament, it was folksong which became synonymous with protest.... Shared ideology also created links between performers of the two musics - [Humphrey] Lyttelton joined [A. L.] Lloyd as a Vice-President of the Workers' Music Association and prominent jazz and folk musicians appeared on the same platform at political events. (Boyes 1993, pp. 214-5)

CND was formed in 1958 (see Taylor 1988; Hinton 1989). Although there had been in Britain small-scale campaigning against nuclear weapons before, it was the development of the super-destructive hydrogen bomb by the United States and then the Soviet Union in the early 1950s, followed by the British government's decision in 1955 to produce its own H-bomb, that really sparked what would become CND. In 1957, the first British H-bomb test took place at Christmas Island in the Pacific, while later the same year the government announced that American Thor nuclear missiles would be sited on airbases in East Anglia. Against such a backdrop, and with Cold War paranoia fully in the air, CND was formed from an extraordinary alliance of supporters, including many artists and musicians, across generations and belief systems, religious and political. Its activities included mass national demonstrations and international campaigning, and related groups were involved in local direct action protests and extensive civil disobedience. The second great wave of support for CND in Britain came in the 1980s, with the introduction of US-controlled cruise missiles on British and European territories. Again, mass national demonstrations featured, but there were also developments in the wider movement: the peace camp movement, a much stronger articulation of the relation between gender and militarism, the use of the pop festival (Glastonbury) for fundand consciousness-raising.

The idea as well as organisation of the first march to Aldermaston actually came from an existing group, the Direct Action Committee Against Nuclear War, but CND quickly realised the potency of such mass street protest. It was this event, this performance of mobilisation, that caught the imagination - indeed, Meredith Veldman goes so far as to argue that, '[w]ithout the march, CND would have been just another largely left-wing protest movement' (Veldman 1994, p. 137). The town of Aldermaston in Berkshire was chosen as the focus because this was the location of Britain's Atomic Weapons Research Establishment. CND's characteristic mix of (sub-)cultural and political protest would become more familiar in the 1960s, as David Widgery recognised: Aldermaston 1958 was 'a student movement before its time, mobile sit-in or marching pop festival; in its midst could be found the first embers of the hashish underground and premature members of the Love Generation' (Widgery 1976, p. 104).

In recognising the improvisatory spirit of the first march in those hectic few months, the fact that jazz should be its soundtrack begins to appear less surprising. John Minnion was a volunteer at CND's national office in London during the period 
leading up to each march. A long-time CND activist, co-editor of the 1983 book, The CND Story (Minnion and Bolsover 1983), trad trumpeter, club and festival organiser, Minnion explains his role in the organisation and motivation of jazz on the marches:

CND realised that bands were springing up spontaneously along the march, and so thought they'd use them. Flyers sent out to prospective marchers asked for addresses etc., but also had a line for people to complete: 'I can play ... and am willing to be in a band'. So if we at national office knew we'd be getting several bands' worth of musicians we'd use them. CND identified a fundamental flaw in conventional politics: let's live, not destroy the world. So: let's have a good time. So: jazz and dance!

There was a luggage wagon that would pick up and drop at the head of the march. Bands would play on pavements as the marchers approached and went by, and then they would get moved along by the wagon periodically. Also some parade bands played: Ken Colyer's Omega Brass Band would always play the last mile. Colyer was hungry for an audience for the parade band, but I'd say he personally was fairly apolitical. There just happened to be lots of marchers from Aldermaston each Easter, the ideal - well, the only situation for a parade band. (Personal interview, 12 December 2001)

The Easter marches became the annual spectacle of the nuclear disarmament movement, recognised nationally and internationally, attracting thousands of mostly middle- class protesters from constituencies as varied as anarchists and MPs, clerics and beatniks, the New Left and the Woodcraft Folk - 'a decent British sort of protest', in Widgery's words (Widgery 1976, p. 104). In CND there was rapid recognition of the possibly innovative cultural identity of the movement, and the importance of culture for energising campaigners and maintaining a high public profile. The Aldermaston marches, and their musics, were constantly referenced. In her autobiography entitled Left, Left, Left, campaign secretary Peggy Duff recalls a characteristic CND politico-cultural event at the Albert Hall in London from November 1961:

we wanted to run something more than a meeting, to hold a mirror up to the movement, to show its variety, its confidence, its ebullience, its political content, its diversity.... [W]e had moving coloured lights on a great white backcloth, and Humphrey Lyttelton (who really understood what we were trying to do) and his band, and George Melly, the Polaris singers from Glasgow, and, real old Aldermaston March stuff - the Alberts who had always led the early marches with whippet and trumpet. It was a crazy mix up of jazz and folk and farce, and colour, and speeches about the Bomb - hard and soft politics, but which was the hard and which the soft I am still not sure. (Duff 1971, p. 210; emphasis added)

This political meeting, this self-regarding 'mirror', is already a retrospective on the movement community's part, celebrating its energetic near-instant history, and the 'crazy mix up' of performance and politics became central to the CND style. It is also very clearly an organised chaos, capturing the moving spirit of Aldermaston within the confines of the Albert Hall.

Jazz music and musicians played their part in the campaign. Trumpeter, critic, broadcaster Humphrey Lyttelton, who had started out in the Dixieland revival in George Webb's band of the 1940s, was a regular supporter, and indeed, according to Jeff Nuttall, a member of Barnet branch of CND (Nuttall, personal interview, 13 December 2001). In 1960, jazz singer George Melly was an original member of the Committee of 100, and he was arrested and fined at one of the movement's mass civil disobedience sit-downs in central London (Melly, personal interview, 25 February 2002). Ian Campbell, better known from the 1960 s folk scene, traces the development and intertwining of music and movement: 


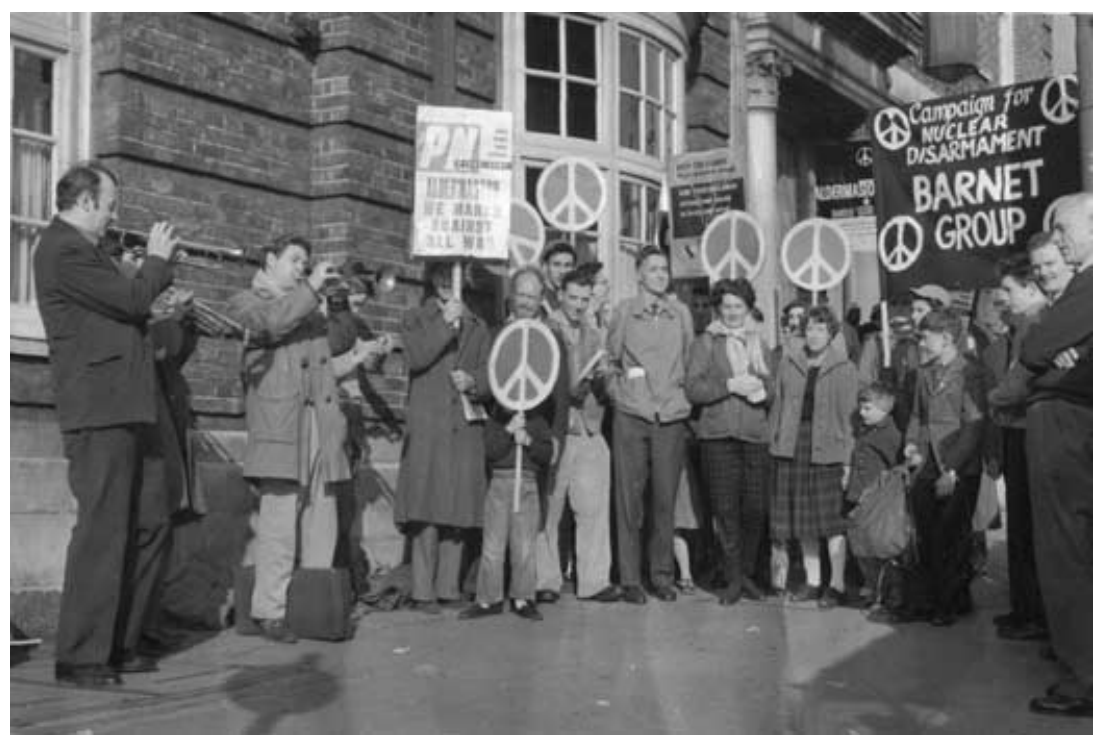

Figure 3. Humphrey Lyttelton (far left) and Jeff Nuttall blow a chorus for Barnet CND, London 1960.

It is significant that 1958, the year that saw the climactic boom in jazz popularity, also produced the first Aldermaston march. The jazz revival and the rise of CND were more than coincidental; they were almost two sides of the same coin. Similar social attitudes and positive humanist values informed them both. At any jazz event a liberal sprinkling of CND badges, and perhaps even leaflets and posters, would be in evidence; conversely, at every CND demonstration live jazz music set the tempo for the march. (Campbell 1983, p. 115)

The live jazz setting the tempo for the Aldermaston marches was invariably provided by some form of brass band, however loosely that might be defined on the day: marchers 'stepped to the parade jazz of a New-Orleans-style marching band beneath the black flag of Anarchism' (Oliver 1990, p. 81). Is it too fanciful to suggest that Aldermaston was a (greyer, colder) British Mardi Gras, 'our own brisk little wrong-end-of-the-telescope version of New Orleans', in Philip Larkin's description of the trad scene (Larkin 1985, p. 78)? The promenading into Trafalgar Square at the end of the march from 1959 on, when marchers and sympathisers formed huge crowds, led by the uniformed parade stepping of the Omega Brass Band, with behind any number of bands and musicians blazing out jazz and other musics, must have felt powerfully carnivalesque. Playing his own cornet loudly, Jeff Nuttall was attracted to the youth contingent of 'Colyer fans... [who] appeared from nowhere in their grime and tatters, with their slogan daubed crazy hats and streaming filthy hair ... blowing their antiquated cornets and sousaphones ... It was this wild public festival spirit that spread the CND symbol through all the jazz clubs and secondary schools in an incredible [sic] short time. Protest was associated with festivity' (Nuttall 1968, p. 51).

On the marches, there was a mixture of professional, ad hoc and amateur New Orleans-style brass bands. Steve Lane is a cornettist with over fifty years playing experience. Before the Second World War he was a member of the Communist Party; following it he relaunched Jazz Music, the then moribund magazine of the anarchist-tinged Jazz Sociological Society. Lane led a band on 'three or four' marches: 
The way I got involved with a marching band was I think that John Minnion rang me up and asked if I could put a band together. I would ring around a bit and get some good musicians together. Some might have been going on the march anyway. One year, the first we did it I think, going to London [so at earliest, 1959], they put the band at the back of the march, so that all the people would be able to hear it - there didn't seem much point in having us leading it, blowing ahead to no one. After one or two of those, they decided to have the band marching from the front, give it a bit of focus. Then came the innovation of us playing on the pavement, as the marchers passed by. That made it a lot easier for us as musicians, not having to play and march for hours.

We didn't get paid, even though we were sort of booked for the event. We regarded it as a political thing and wouldn't expect to be paid. Though we were there as a parade band we never wore uniforms - [my regular band] the Southern Stompers had been wearing uniforms for years for our gigs, but for Aldermaston there was a general feeling to be free and easy on the marches, a bit of that pre-60s teenage relaxing, I suppose. In terms of repertoire, at that time Colyer's band knew all the correct brass material for parades, him having famously been to New Orleans. But at Aldermaston we played more in the line of classic 1920s jazz, with less marches or authentic parade music. (Lane, correspondence and personal interview, 16 January 2001, 11 January 2002)

Jeff Nuttall's experience of brass band playing at Aldermaston was characteristically less authentic still, blurring British military and American jazz band traditions, and taking advantage of the satirical opportunities of performance and place:

I was part of the so-called Aldermaston Jazz Band. We played 'Land of Hope and Glory', badly and ironically. It was our aggressively satirical version of the tune, played at Parliament Square at the end of the march in I think 1959. We set up outside the Ministry of Defence as part of the Aldermaston show. Ours was a Portsmouth Sinfonia version, as only [cornettist] Dougie Gray knew the tune! It was received by the passing marchers with the understanding the Woodstock audience would have a decade later listening to Hendrix playing 'The star-spangled banner'. We were anti-royalist, anti-military, anti-pomp, but no we were not anti-American. We were not pro-empire either, a sort of 'comic' nostalgia maybe. (Personal interview, 13 December 2001)

In their different ways, Lane and Nuttall foreground the importance of repertoire and setting for the performance. For Lane's band, the initial choice was between being heard and being seen, combined with whether the music was primarily for participants or observers: playing at the rear of the march meant the music projected onto the marchers, for their benefit, while playing at the front meant there was a visual focus, more oriented to outside observers. Nuttall's was more of an informed contumacious gesture: playing Elgar's Victorian march at the end of a kind of peace march seems both to question and confirm the mock (post-) imperial position of many of the younger CND-ers, and playing it badly outside the Ministry of Defence was a critical defamiliarisation. On other occasions, too, musicians displayed sensitivity to their surroundings through their performances. For example, the film March to Aldermaston shows the marchers walking in silence as they leave Trafalgar Square on Good Friday and again on the approach to the nuclear facilities at Aldermaston on Easter Monday (the narrator explains the significance of the silences). The musicians' use of dynamics underlines the marchers' reflexive awareness of performance, the carnival's undermining of the distinction between outsider and participant. It is important also to stress the very space of performance, and its accessibility to people who wanted, and others even who did not want, to hear the music: open air music in the streets destroys the enclosure - (re)claims the street and challenges the hierarchy of concert and club. Colin Barker recalls experiencing a Colyer-led brass band as a teenager in Essex in 1958 or 1959: 'It felt like a rebellion 


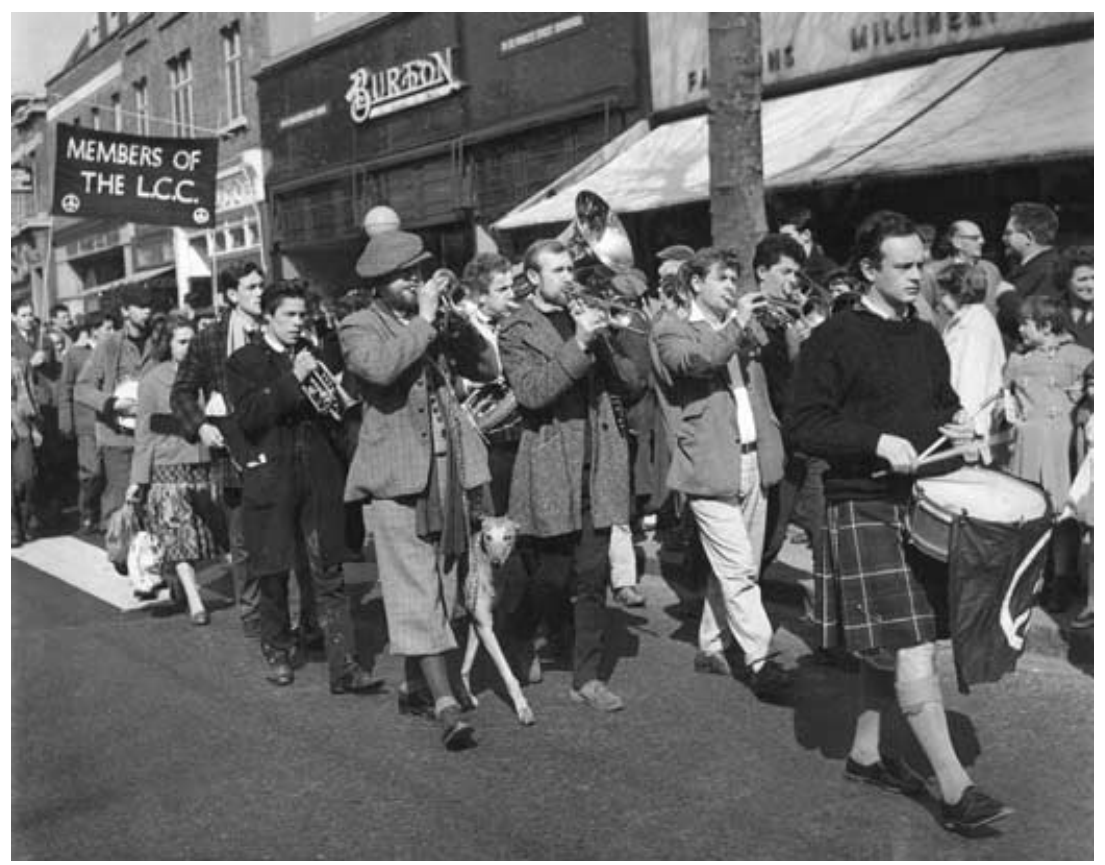

Figure 4. 'The Aldermaston Jazz Band', including English eccentrics the Alberts (brothers Dougie Gray on pocket cornet with greyhound, Tony Gray on piccolo trombone), between them the Temperance Seven's Martin Fry (sousaphone), Jeff Nuttall (trumpet, their left), 1959 or 1960.

[just] marching through respectable Barkingside High Street with that band' (personal correspondence, 22 April 2002).

The ad hoc nature of the bands led by Lane and Nuttall mitigated against the formal wearing of uniforms, and Colin Bowden, one of the surviving members of the Omega Brass Band, explains that even the Omega's early efforts at such authentic New Orleans touches were less than convincing.

We never practised the shuffle or stepping. No, none of that. In fact it was a shambles, that side of it! In the very early days the effort at being authentic, with uniforms and performance and all, was absolutely minimal - it was always, for the musicians, the music first and foremost. The uniform was basically black trousers, white shirt and tie, and a peaked cap. Ken worked for London Transport at the time, and he managed to get a load of London bus drivers' or conductors' caps, and we used them for the uniform. [Laughs] (Bowden, personal interview, 10 April 2002)

The terrifically mundane combination of signifiers recalled by Bowden here - New Orleans parade band topped by something from a red double decker bus - may stand as an emblematic moment in transatlantic cultural exchange around jazz in Britain, not unlike the English bowler hat adopted by 'pre-atomic' (Melly 1970, p. 60) tradder Acker Bilk and identified by Philip Larkin above as curiously iconic. Yet I think Bowden underplays the visual impact even a limited uniform and choreography could have: in photographs of marches the Omega always stands out, partly because the band always led - but then it may have deserved to lead precisely because of its visual and musical confidence. Also, it was not strictly a marching music, rather a step-march or shuffle was the aim of the band - perhaps the 'syncopated sensibility' Les Back suggests as an anti-totalitarian movement of the 
jazz body (Back 2001, p. 193). The music did attract people too: Jazz historian and photographer Val Wilmer was an enthusiastic member of 'the second line' on two Aldermaston marches.

We joined the 1960 march on the final day, as it came into London. Ken Colyer's Omega Brass Band played - that was a good occasion for them. The bowler hat with a CND symbol on the front was a big fashion item on the marches then - after Acker Bilk was no. 1 in the charts at the time. In 1961 I did the whole march, sleeping in school halls along the route. Lots of brass bands played - there were always bands playing. They made the event more appealing. I did go for CND, but the bands were an exciting extra. We'd always try to be behind a band on the march, we'd position ourselves with an ear on the music. (Wilmer, personal interview, 24 January 2002)

\section{Ken Colyer and the Omega Brass Band}

The awkward, stubborn figure of Ken Colyer keeps appearing in different peoples' narratives of trad and Aldermaston. Though he had led an informal parade band in England prior to his US adventure, Colyer was inspired by the funeral parades he saw in New Orleans in 1952-1953, featuring the Young Tuxedo Band and the Eureka Brass Band (Colyer 1970). This produced within a couple of years of his return the Omega Brass Band, uniformed, capped (with OMEGA on their hatbands, and LEADER on his), step-marching in time, playing what was thought of as a wide and authentic repertoire. Bowden, the Omega's original snare drummer, here traces its origins and practice:

The Omega Brass Band was formed for the first Soho Fair, held on June 1st 1955. Ken Colyer held a residency at the 51 Club and he was asked to play for the Soho Fair, and he saw it as an opportunity to form a proper marching band. The way it happened was Ken and Sonny Morris, who'd both been together as trumpeters in the Crane River Band a few years before, each now led a six piece New Orleans band. They put these two together to produce a marching band for the Soho Fair, with musicians swapping instruments as necessary - so Johnny Bastable, Ken's banjoist in the normal band, played bass drum in the parade band.

There had been street bands before, and the Cranes had done things like carnivals and fairs, but that was sitting on the backs of lorries, or playing at the side, with banjos and so on. There had never been marching jazz bands up till then, not proper New Orleans style, like the ones Ken had seen doing funerals in New Orleans. So yes, we were the first - Ken's band set the pattern for the whole British scene. Others like the New Taeo Brass Band came along later.

The line up of the Omega varied considerably - but would generally feature some mix of two trumpets, two trombones, clarinet, E flat horn, tenor and alto saxophone, sousaphone, and snare and bass drums. Head arrangements were the main repertoire. We didn't have books of arrangements written out for us to read as we marched. We played by ear. The brass band played what the ordinary band played, so we knew all the tunes from our normal repertoire. (Personal interview, 10 April 2002)

Aldermaston was a grand occasion for the Omega Brass Band, evidenced by the fact that the band would expand for the occasion, and that there was a significant 'second line' of CND-ers and/or parade marchers following along, as Bowden remembers: 'when Omega turned up to play the last mile of those marches, we would try to have a bigger line up than normal - three trumpets, three trombones, that sort of thing. And on the Aldermaston marches we'd always have a mass of fans behind us, marching with us' (personal interview, 10 April 2002). Writing in 1958, David Boulton speculates on the cultural and political potential of the parade band, of this jazz in the streets of Britain: 
Ken Colyer's experiments with the Omega Brass Band and his attempts to establish a British marching style could spark off such a new music. If we were to bring jazz out into the streets of our towns and cities, reviving the functions and parades which characterised old New Orleans, then jazz might once again develop a music of the people, moving perhaps from jazz as we know it to a new and self-contained urban folk-music. (Boulton 1958, p. 137)

We have seen that the reinvigorated 'music of the people' Boulton desires (presumably after Finkelstein 1948) was, in its original African-American form, precisely that. It is clear that Colyer and the many other musicians who played jazz in formal and ad hoc brass bands for anti-nuclear and left demonstrations and rallies were not only importing and imitating an exoticised practice, they were also recognising, even extending, the socio-political tradition of that type of music-making. John Hutnyk makes a useful distinction between the negative hermeneutic of 'imitation' and 'derivation' in global music, and a less reductive, potentially liberatory acknowledgement that solidarities can be recognised across quite different sociocultural formations (Hutnyk 2000, p. 214) ${ }^{6}$ Colyer felt that he was taking on the mantle of the New Orleans parade tradition, and trying to create a new audience for that music, a gesture of solidarity:

As I watched the street parades in New Orleans I noticed the reaction of the different age groups. The older people really enjoyed the music, and the children were just crazy about it, laughing and dancing along the roadside. But the teenagers and young men showed no emotion whatsoever.... Unless a new generation comes up that can break away from this pattern and look at things objectively and realise the social bug is not important, the genuine home grown New Orleans jazz will die with the last of the old masters. (Colyer 1970, p. 62)

The excited second line following Omega at the Soho Fairs or the Aldermaston marches is compelling evidence of Colyer's fulfilled ambition: he really did present parade music to a new generation of teenagers and young people. They embraced it then, and it has continued. Looking round the country to provincial political cultures it is possible to trace significant leftist jazz street music. In Bristol, for example, the Great Western Marching Band would often be found accompanying political demonstrations, while

the Pioneer Jazzmen played in the cellar of the Communist Club in Lawfords Gate. The band started around 1961 ... [and in brass band form] were much sought after to be the vanguard of the many gatherings that took place in the city at that time. Supporters of Anti-Apartheid, Human Rights, CND and Trades Union activities were often cheered by the band's presence. (Hibberd 2000, p. 29)

Modern jazzers became interested, too. In the early 1970s, Mike Westbrook's Brass Band project developed into a conscious effort to re-present some of the earlier New Orleans street band tradition, interestingly crossed with the British brass band tradition. Westbrook recalls the sunny 1973 Bath Festival fringe:

The weather had a lot to do with it! I think Lol [Coxhill] was there and a few others, so this street band began, playing a very crude simple sort of music, but philosophically just the right thing, being simple and direct, and having to do with just having fun and giving pleasure to people. And it also had those echoes of the notion of the New Orleans idea; and our very distant equivalent couldn't be compared in seriousness, but was our idea of music for the community ... we very much thought of ourselves as a street band, a Sally [Salvation] Army-type thing. (quoted in Wickes 1999, p. 279)

The Westbrook Brass Band, soon including more sophisticated arrangements by the likes of free jazz trombonist Paul Rutherford (who had started out in the 1950s 


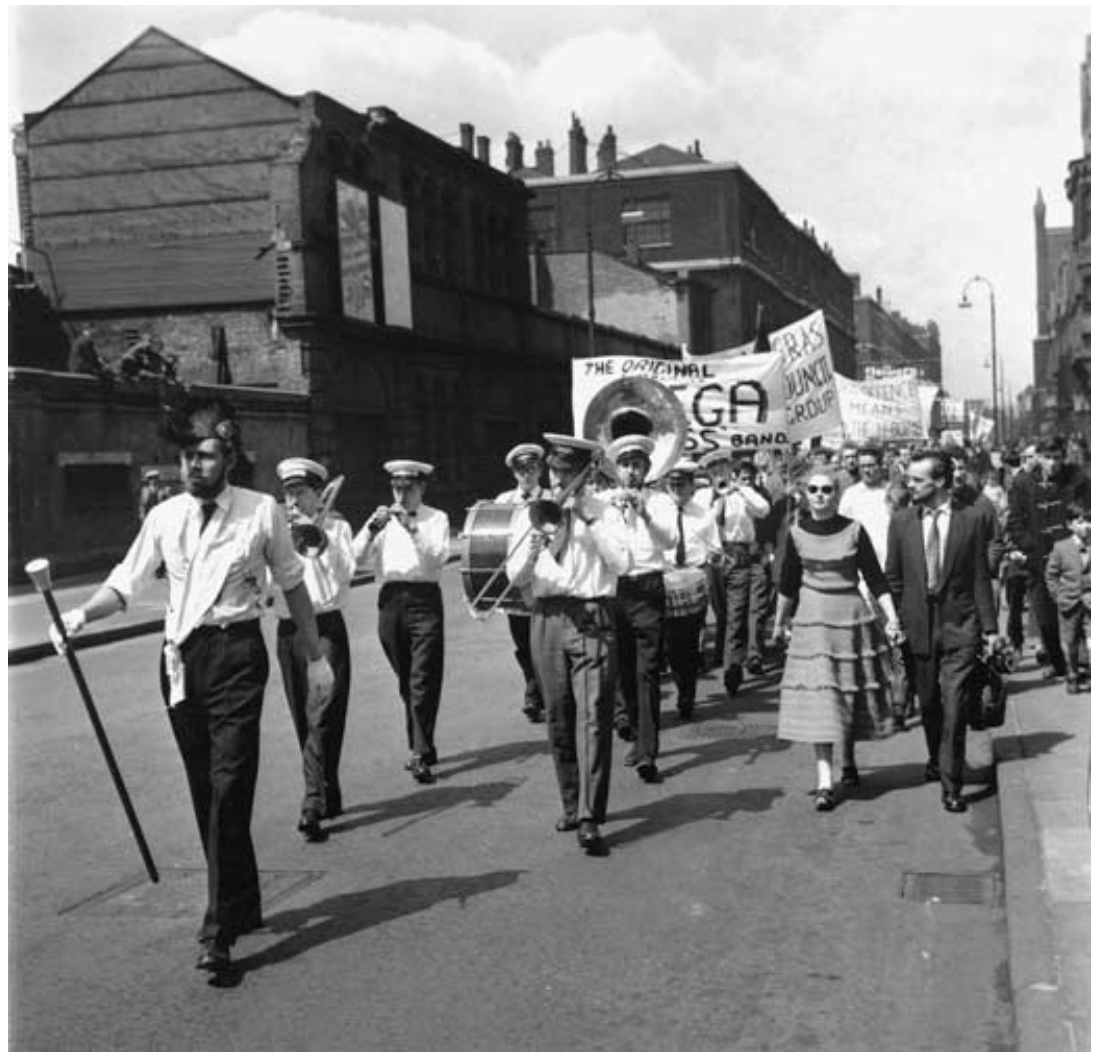

Figure 5. Omega Brass Band, CND march, late 1950s or early 1960s. Note the Grand Marshall leading the band, and the very stylish 'second liners'.

playing around in amateur trad bands; Wickes 1999, p. 42), began to play outside the jazz circuit - at communist gatherings, in housing estates, outside factories, as well as at theatre and community festivals.

Yet in interviews with musicians, fans and critics about Colyer, I found any clear political position always difficult to locate. On numerous occasions I was told that Colyer was in no way political, that he was simply a musician looking for the best audiences. Other, politically active, musicians stressed to me that they rarely made any conscious links between their politics and their music. Further, a number of autobiographies of key jazz musicians from the time are remarkable for the sheer lack of space given to their own authors' political campaigning (see Lyttelton 1958; Melly 1965, for instance). But Bob Wallis, a bandleader as well as a member of the Omega Brass Band, has linked Colyer's implicit politics with those inscribed in the music itself. In his fifties, Wallis studied for a degree and wrote a highly informative undergraduate dissertation on the trad scene. He argues that, for Colyer, 'the Bunk Johnson band provided the perfect example of collective improvisation, with the musicians working together for the good of the whole sound... "Fair shares for all" had been a rallying cry of the war years, ... and that was the economic as well as the musical principle on which the Revivalist bands [such as Colyer's] worked' (Wallis 1987, p. 10). Colyer and Wallis's drummer of the period, Colin Bowden, contributes to the problematic here: 
The main thing for us was that a march provided a platform for the music. We weren't socialists using music to make a political point - we were musicians who happened sometimes to play at some political events. Of course, we might have got more political jobs because we played on the Aldermaston marches. If there was another socialist gathering, a May Day march for instance, well they'd book a parade band, to get the Aldermaston spirit, or feeling. In that way the two became connected, perhaps. The New Orleans style was swing on wheels really, perfect for those marching occasions. On the other hand, the Musicians' Union would supply bands for Trades Union events, and we weren't in the MU - we wouldn't have anything to do with it because of the ban on American musicians that was still going on then [ended 1956]. So that might have closed down options. (Personal interview, 10 April 2002) ${ }^{7}$

It is important then to acknowledge that a political reading of the musical performance can itself be partial. Further, Alan Bonney of the Ken Colyer Trust recalls an event which problematises the relation between the music and ideological positioning:

A good example to look at is the Suez War demonstration in London in 1956, the big one in Trafalgar Square. I was there. Lots of bands played there, and yet among the anti-war demonstrators there were spread groups supporting the government line - the National Union of Seamen marched under pro-banners at Trafalgar Square! You've got groups supporting and groups opposing the [British] military action at the same national demonstration, and brass band jazz music swirling around everywhere. So you can't identify a simple link between music played and political alignment. (Personal interview, 19 January 2002)

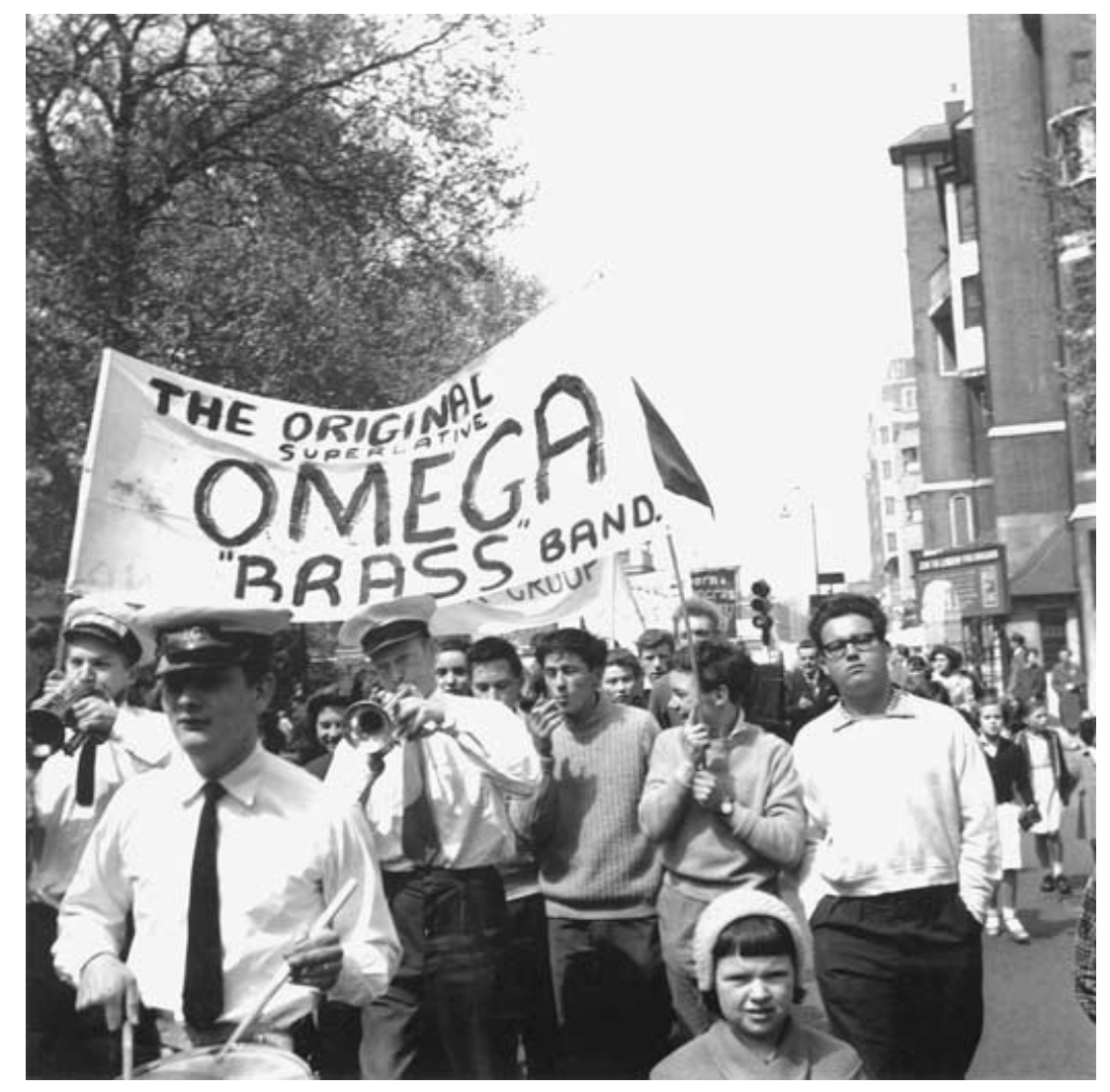

Figure 6. The 'original superlative' Omega Brass Band, CND march, late 1950s or early 1960s. From left: Ken Colyer (trumpet), Colin Bowden (snare drum), Bob Wallis (trumpet). 
Suez was a difficult situation for the left as a whole to come to terms with politically, but even here it is trad jazz that accompanies the political marchers. It is worth stating that I have found no evidence at all of the music accompanying political processions or gatherings of the right, or nationalist or fascist during this period.

\section{Conclusion: trad jazz and national cultures}

It is possible to see in this important but hitherto neglected part of the trad scene of the 1950s not (just) the suburban 'safe' mentality of Little England, not (just) tea on mowed lawns, conservative nostalgia or a bleaching or romanticisation of a culture of struggle - but also, an early contribution to what Baz Kershaw calls 'the typical counter-cultural thrust of celebratory protest' (Kershaw 1992, p. 68) characteristic of the 1960s and after movements, and practised by someone like Jeff Nuttall, moving from blowing his cornet at Aldermaston to the happenings-style People Show of the mid-1960s and onwards. As one of a number of carnivalesque developments in Britain at the time - the Beaulieu Jazz Festivals of 1956-1961, an early Caribbean-style carnival in Notting Hill, London in 1959 are others associated with popular music (see McKay 2000A) - Aldermaston stands out as the most clearly politicised.

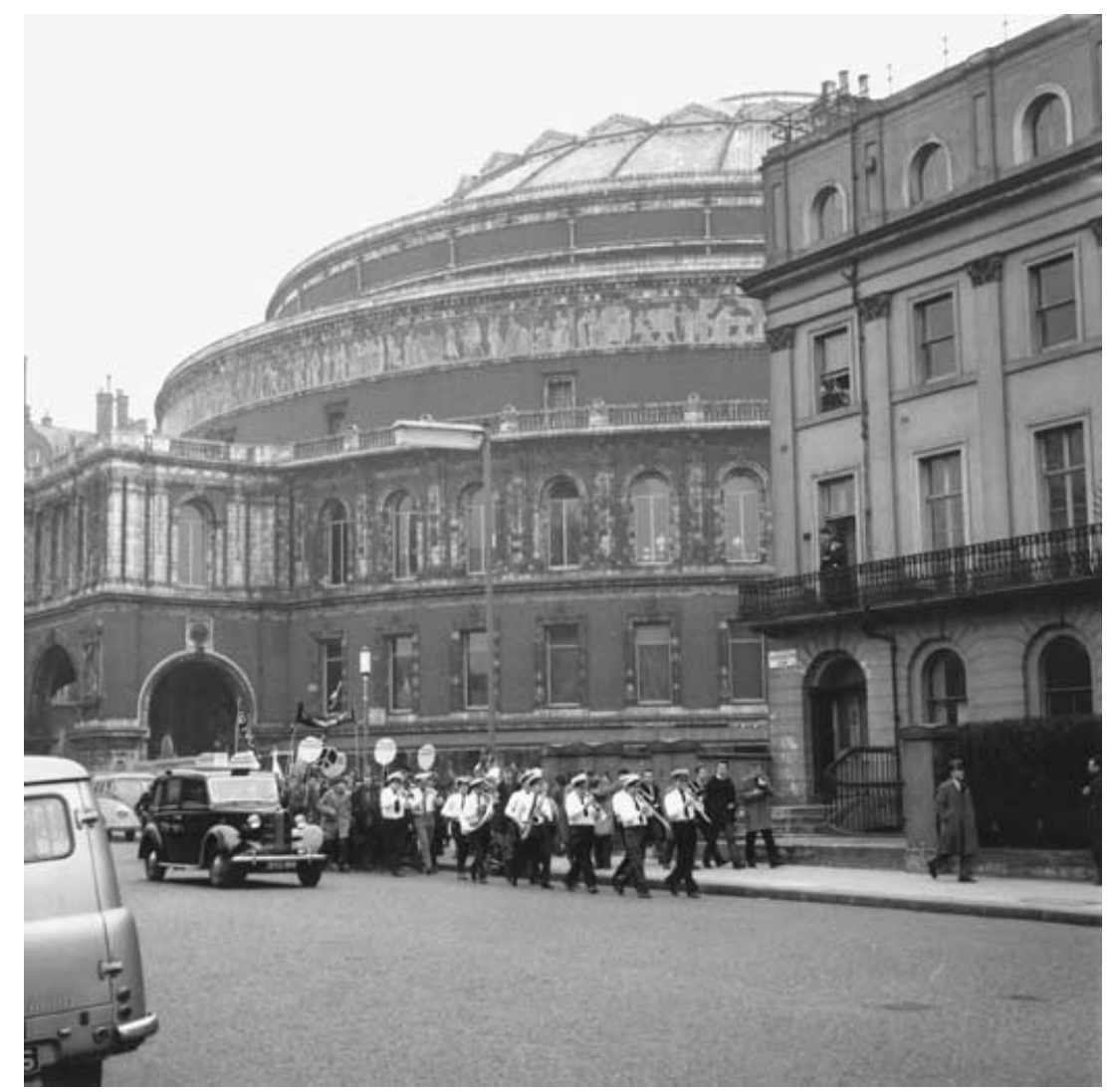

Figure 7. Omega Brass Band, Aldermaston CND march, contesting empires: American-style jazz marching for peace past the Royal Albert Hall, late 1950s or early 1960s. 
In Bomb Culture Nuttall argues that British musicians and activists choosing the 'small-band collective improvisation of twenties New Orleans jazz ... was a natural reaction after the harsh metal of war. It was a hungering for the green and intuitive life, almost for the pastoral' (Nuttall 1968, pp. 41-2). The collective excursion through the English Home Counties countryside that was the Aldermaston march satisfied further this 'hungering ... for the pastoral'. He elaborated to me on 'primitivism as a mode of the times. For CND-ers, for trad, it signified in the nomadic gesture of Aldermaston, in the barefoot dancing to acoustic music.... A great cult of dirt - black jeans, duffle coats or donkey jackets, straggly hair, unkempt' (personal interview, 13 December 2001). The embracing of trad jazz exemplifies the strong atavism found in CND and the early Green movement (see Veldman 1994). In many ways, trad jazz did blow against 'the presentist bias of modern society' (Veldman 1994, p. 306). But interwoven problematically within this reading is the position of that presentist society par excellence, the United States, and its export cultures and related (in this instance, British) fears of Americanisation and standardisation. From Veldman's choice of JRR Tolkien to the folk revival, atavistic national cultures are re-employed for a new or alternative national identity across romantic protest, which in the 1950s and early 1960s meant CND. 'The sense of national identity', continues Veldman,

was often accompanied by anti-Americanism. To these romantic critics the United States represented the future to avoid, a society devoted to growth and speed and endless change, a nation without a sense of tradition, a collection of individuals rather than a community.... Anti-Americanism linked the concern for Britain's identity and role in the world... [to] antimaterialism. (Veldman 1994, p. 306)

As we have seen, jazz complicates this one-way gaze (see also McKay 2000в). Tradders and CND-ers found in their version of this American music the very attributes Veldman suggests they thought were missing from American society: not speed but walking, continuity, tradition, community, anti-commercialism. There is at least one final irony here. While one brass band culture in Britain began to flourish, another was wilting. The long-standing British tradition of working-class and Salvationist brass band playing seems not to have been of any interest to the novel New Orleans-style bands like Omega, New Taeo, Great Western that formed from 1955 on. In fact, notes Dave Russell, '[u]nder the impact of the 'Americanisation' of popular music, the brass band, that most British of musical institutions, had lost its privileged position in the popular musical culture of industrial Britain' (Russell 2000, pp. 108-9). The composer Hubert Bath observed of the national brass band festival in 1930 that 'It was a joy to me as a musician to know that the musical backbone of our country, north of Luton, is not and, it is hoped, never will be at the mercy of the American invasion. The breath of our good, honest, fresh brass air from the north was, and always will be, an invigorating tonic to the jaded, Americanised southerner' (quoted in Russell 2000, p. 112). A quarter of a century and a world war later, it was those Americanised southerners, led by Ken Colyer, that were blowing their own 'good, honest, fresh brass air' - new musicians, new audiences, new brass band music, New Orleans.

\section{Acknowledgements}

This research was made possible in part by an Arts and Humanities Research Board small grant in the creative and performing arts, awarded in 2001. I am very grateful 
for the Board's support. I would also like to thank Les Back, Eric Benner of CND, Professor Andrew Blake, Roy Gallop, Robert Greenwood, David Horn, David Nathan of the National Jazz Foundation Archive at Loughton, Essex, my colleague Dr Alan Rice, Dr Graham Taylor, Professor Helen Taylor, Susan Tomkins and other staff of the Beaulieu Motor Museum archives, and the editors of Just Jazz magazine. Also sincere thanks are due to those involved from the scene who corresponded or kindly agreed to be interviewed: Alan Bonney, Brian Harvey and Peter Hunter from the Ken Colyer Trust (www.kencolyertrust.org), Colin Barker, Colin Bowden, Steve Lane, George Melly, John Minnion, Jeff Nuttall and Val Wilmer. Edited transcriptions of these interviews, interspersed with images, can be found at: $<$ www.uclan.ac.uk/facs/class/cultstud/staff/mckaytext.doc $>$. I would also like to acknowledge the extremely useful comments from the two anonymous readers of an earlier version of this article.

Picture acknowledgements are due as follows - and I am extremely grateful for permission to use them. Pictures 1, 3 and 4, courtesy of Jeff Nuttall's personal collection. Used with permission. Picture 2 (photographer John Hollington), and pictures 5-7 (photographer Peter Vince), courtesy the Ken Colyer Trust archive. Used with permission. Copyright Ken Colyer Trust.

\section{Endnotes}

1. Conscious of the irony of complaining about neglect in a footnote, I should nevertheless point out that, in the space of a very few years up to the mid 1950s, cornettist Ken Colyer championed purist New Orleans ensemble jazz, and played a key founding role in three significant areas. With various bands before and after his New Orleans adventure in 1952-1953 he led the trad movement - his musicians Acker Bilk and Chris Barber went on to take the commercial plaudits; second, he introduced skiffle between sets, and his musician Lonnie Donegan took the hit singles; third, he introduced to Britain what I believe to be the first New Orleans style parade band, the Omega Brass Band. At the 100 Club in London, Colyer's contribution is seen in an entire wall of photographs, with a large commemorative plaque. (Compare the fact that, opposite, photographs of the likes of Mick Jagger and Pete Townsend onstage at the club are altogether smaller and more poorly presented, while the now legendary 1976 Sex Pistols concert there is allotted no wall space whatever.) Bands such as the Rolling Stones and skifflers the Quarrymen - who went on to bigger things as the Beatles - played in between sets at Colyer concerts. Taylor notes that Colyer's achievements have been acknowledged or formally recognised by Paul McCartney, New Orleans City Council and the British Government (Taylor 2001, pp. 111-12). Academia has been less kind.

2. Though Richard Palmer and John White's later edition of Larkin's uncollected writings on jazz seeks to challenge this: 'Larkin's views on the development from diatonic- to chromatic-based jazz amount to something much more complex than mere rejection' (Palmer and White 1999, p. 128, n. 36). As evidence, they point to Larkin's Daily Telegraph Records of the Year through the 1960s, which cite Thelonious Monk (for 1964), John Coltrane (1965), and even Ornette Coleman (1967). Miles Davis's Miles in the Sky is a record of the year in both Larkin's 1968 and 1969 columns (Palmer and White 1999, pp. 164-6).

3. The Battle of Beaulieu, as it was inevitably dubbed, in 1960, saw the festival stage destroyed, lighting rigs torn down, a building set alight, thirty-nine people injured, and BBC television's live outside broadcast stopped six minutes before its scheduled end, with a commentator's interruption: 'Things are getting quite out of hand. [Pause] It is obvious things cannot continue like this'. Prior to this announcement, viewers had heard a commandeered BBC microphone used to demand 'More beer for the workers!' (Beaulieu Motor Museum Archive, 1960 Beaulieu Jazz Festival press cuttings file; see also McKay 2000A, pp. 1-6).

4. The brass band parading with a procession and supporters alongside ('the second line') was also a black cultural expression of urban presence and power, of reclaiming the streets. Schafer reports the well-known Onward Brass Band on a Sunday afternoon procession in 1890: 'The procession reached the corner of Magazine 
and Washington... when the negroes on the sidewalk were attacked by a force of young white men, who pelted them with rocks, etc. This was a signal for a general battle on all sides. The entire neighbourhood turned out. ... The greatest excitement prevailed and several people made their appearance armed with shotguns. The paraders and members of the band also took a hand in the row...' (quoted in Schafer 1977, pp. 26-8).

5. Colin Bowden, Colyer's drummer from the mid-1950s, remembers that 'the Russell recordings were the influence for us - Ken had seen parade bands in New Orleans [in 19521953], but for the rest of us it was those recordings from a few years earlier that we list- ened to. We also had the records of the Eureka Brass Band - we'd sit down and listen carefully, play along, and work out our lines. There were no written parts' (personal interview, 10 April 2002).

6. It should be noted though that jazz clubs are cited by Hutnyk in a long list of examples of the derivative nature of European culture. His point about solidarities is more directed at different black musical formations.

7. Note the rapid 'mobilisation of tradition', to use Eyerman and Jamison's term (1998, pp. 41-5), here: the powerful, seemingly instant tradition of New Orleans-style music on CND marches is mobilised by the left more widely for its politico-cultural energy and innovation.

\section{References}

Back, L. 2001. 'Syncopated synergy: dance, embodiment, and the call of the jitterbug', in Out of Whiteness: Colour, Politics and Culture, ed. V. Ware and L. Back (London), pp. 169-95

Beaulieu Motor Museum Archive. 1960. Beaulieu Jazz Festival press cuttings file

Blake, A. 1997. The Land Without Music: Music, Culture and Society in Twentieth Century Britain (Manchester)

Boulton, D. 1958. Jazz in Britain (London, 1959)

Boyes, G. 1993. The Imagined Village: Culture, Ideology and the English Folk Revival (Manchester)

Brunner, J. 1983. 'Music on the march', in The CND Story: The First 25 Years of CND in the Words of the People Involved, ed. J. Minnion and P. Bolsover (London), pp. 45-7

Campbell, I. 1983. 'Music against the Bomb', in The CND Story: The First 25 Years of CND in the Words of the People Involved, ed. J. Minnion and P. Bolsover (London), pp. 115-17

Chambers, I. 1985. Urban Rhythms: Pop Music and Popular Culture (London)

1986. Popular Culture: The Metropolitan Experience (London, 1990)

Colyer, K. 1970. New Orleans and Back, 2nd edition (Kent, 1992)

Duff, P. 1971. Left, Left, Left: A Personal Account of Six Protest Campaigns 1945-65 (London)

Eyerman, R., and Jamison, A. 1998. Music and Social Movements: Mobilizing Traditions in the Twentieth Century (Cambridge)

Finkelstein, S. 1948. Jazz: A People's Music (London, 1964)

Frith, S. 1988. 'Playing with real feeling: jazz and suburbia', in Music for Pleasure: Essays in the Sociology of Pop (Cambridge), pp. 45-63

Gendron, B. 1995. "'Moldy figs" and modernists: jazz at war (1942-1946)', in Jazz Among the Discourses, ed. K. Gabbard (Durham), pp. 31-56

Godbolt, J. 1984. A History of Jazz in Britain, 1919-50 (London)

Herbert, T. 2000. 'Nineteenth-century bands: making a movement', in The British Brass Band: A Musical and Social History ed. T. Herbert (Oxford), pp. 10-67

Hewison, R. 1981. In Anger: Culture in the Cold War 1945-1960 (London)

Hibberd, D. 2000. My Kind of Town: Recollections of Jazz in Bristol (Bristol)

Hinton, J. 1989. Protests and Visions: Peace Politics in Twentieth-Century Britain (London)

Hutnyk, J. 2000. Critique of Exotica: Music, Politics and the Culture Industry (London)

Kershaw, B. 1992. The Politics of Performance: Radical Theatre as Cultural Intervention (London)

Larkin, P. 1985. All What Jazz: A Record Diary, 1961-1971 (London), revised edition

Lyttelton, H. 1958. Second Chorus (London, 1959)

March to Aldermaston. 1958. Produced and directed by the Film and Television Committee for Nuclear Disarmament

McKay, G. 2000A. Glastonbury: A Very English Fair (London)

2000B. 'Anti-Americanism, youth and popular music, and the Campaign for Nuclear Disarmament in Britain', in Anti-Americanism at Home and Abroad, ed. S. Mathé (Aix-Marseille), pp. 185-206

Melly, G. 1965. Owning-Up (Harmondsworth, 1970)

1970. Revolt Into Style: The Pop Arts in Britain (Harmondsworth, 1972) 
Minnion, J., and Bolsover, P. 1983. 'Introduction', in The CND Story: The First 25 Years of CND in the Words of the People Involved, ed. J. Minnion and P. Bolsover (London), pp. 9-41

Morgan, K. 1998. 'King Street blues: jazz and the left in the 1930s-1940s', in A Weapon in the Struggle: The Cultural History of the Communist Party in Britain, ed. A. Croft (London), pp. 123-41

Nehring, N. 1993. Flowers in the Dustbin: Culture, Anarchy, and Postwar England (Ann Arbor)

Newton, F. (pseudonym of Eric Hobsbawm). 1959. The Jazz Scene (Harmondsworth, 1961)

Nuttall, J. 1968. Bomb Culture (London)

Oliver, P. (ed.) 1990. Black Music in Britain: Essays on the Afro-Asian Contribution to Popular Music (Milton Keynes)

Osborne, J. 1957A. Look Back in Anger (London)

1957в. 'Sex and failure', in Protest, ed. G. Feldman and M. Gartenberg (London, 1960), pp. 269-71

Palmer, R., and White, J. (eds.) 1999. Reference Back: Philip Larkin's Uncollected Jazz Writings 1940-1984 (Hull)

Russell, D. 2000. “'What's wrong with brass bands?" Cultural change and the band movement, 1918c.1964', in The British Brass Band: A Musical and Social History, ed. T. Herbert (Oxford), pp. 68-121

Schafer, W.J. 1977. Brass Bands and New Orleans Jazz (London)

Taylor, H. 2001. Circling Dixie: Contemporary Southern Culture through a Transatlantic Lens (New Brunswick, NJ)

Taylor, R. 1988. Against the Bomb: The British Peace Movement 1958-1965 (Oxford)

Veldman, M. 1994. Fantasy, the Bomb, and the Greening of Britain: Romantic Protest, 1945-1980 (Cambridge)

Waters, C. 1990. British Socialists and the Politics of Popular Culture, 1884-1914 (Manchester)

Wallis, B. 1987(?). Revivalism to Commercialism: A Study of Influences on the Developing Styles of Ken Colyer and Acker Bilk. Unpublished undergraduate dissertation. No other details. Held at the National Jazz Foundation Archive, Loughton

Wickes, J. 1999. Innovations in British Jazz, Vol. 1: 1960-1980 (Chelmsford)

Widgery, D. (ed.) 1976. The Left in Britain 1956-68 (Harmondsworth) 
